\title{
WOUNDED FEELINGS
}

Litigating Emotions in Quebec, 1870-1950 


\title{
PATRONS OF THE SOCIETY
}

\author{
Blake, Cassels \& Graydon LLP \\ Chernos, Flaherty, Svonkin LLP \\ Hull \& Hull LLP \\ The Law Foundation of Ontario \\ McCarthy Tétrault LLP \\ Osler, Hoskin \& Harcourt LLP \\ Paliare Roland Rosenberg Rothstein LLP \\ Pape Chaudhury LLP \\ Torys LLP \\ WeirFoulds LLP
}

The Osgoode Society is supported by a grant from The Law Foundation of Ontario.

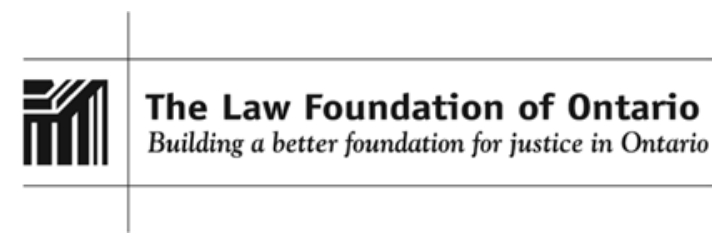

The Society also thanks The Law Society of Ontario for its continuing support. 


\section{WOUNDED FEELINGS}

\section{Litigating Emotions in \\ Quebec, 1870-1950}

ERIC H. REITER

Published for The Osgoode Society for Canadian Legal History by University of Toronto Press Toronto Buffalo London 
(C) Osgoode Society for Canadian Legal History 2019 utorontopress.com osgoodesociety.ca Printed in Canada

ISBN 978-1-4875-0655-1

\begin{abstract}
(6)
Printed on acid-free, $100 \%$ post-consumer recycled paper with vegetable-based inks.

Publication cataloguing information is available from

Library and Archives Canada.
\end{abstract}

University of Toronto Press acknowledges the financial assistance to its publishing program of the Canada Council for the Arts and the Ontario Arts Council, an agency of the Government of Ontario.

Canada Council Conseil des Arts for the Arts

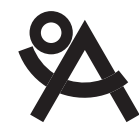

ONTARIO ARTS COUNCIL CONSEIL DES ARTS DE L'ONTARIO

an Ontario government agency un organisme du gouvernement de l'Ontario

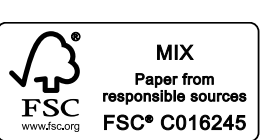

